\title{
HUBUNGAN KADAR ALBUMIN PLASMA DAN GULA DARAH DENGAN SEPSIS NEONATORUM
}

\author{
${ }^{1}$ Ester Elisabeth Wowor \\ ${ }^{2}$ Johnny Rompis \\ ${ }^{3}$ Rocky Wilar \\ ${ }^{1}$ Kandidat Skripsi Fakultas Kedokteran Universitas Sam Ratulangi Manado \\ ${ }^{2}$ Bagian Ilmu Kesehatan Anak Universitas Sam Ratulangi Manado \\ ester.elisabeth14@gmail.com
}

\begin{abstract}
Sepsis is the most leading cause of morbidity and mortality in neonates. In sepsis, the proinflammatory cytokines realeasing leads to disruption of plasma albumin and blood glucose levels. This study aim to analyze the relationship of plasma albumin and blood sugar levels with neonatal sepsis. Prospective observational analytic studies conducted on suspected sepsis neonates at Pediatrics Department Sub Division Neonatology RSUP Prof.Kandou Manado. Diagnosis of sepsis based on clinical symptoms and laboratory tests. Subjects are grouped into two groups of neonatal sepsis and non-neonatal sepsis group (control group). Plasma albumin and blood glucose level examined, then statistically analyzed. The statistical analysis used was Pearson Chi-Square correlation and Fisher Exact. The data were processed using SPSS 21. The results of this study indicate that hypoalbuminemia was found in 12 (75\%) of 16 neonatal sepsis subject, whereas in non-neonatal sepsis only found 5 (22,7\%) of 22 non-sepsis subjects. Statistically there is a highly significant difference $(p=0,001)$. For the impaired blood glucose (both hypoglycemia or hyperglycemia) there is no significant difference between the two groups $(\mathrm{p}=0,466)$. Conclusion: There is a highly significant relationship between hypoalbuminemia with neonatal sepsis. There was no significant correlation between abnormal blood glucose levels with neonatal sepsis.
\end{abstract}

Keywords: neonatal sepsis, plasma albumin levels, blood glucose levels.

\begin{abstract}
Abstrak.Sepsis merupakan penyebab morbiditas dan mortalitas terbanyak pada neonatus. Pada sepsis terjadi pelepasan sitokin proinflamasi yang memicu terjadinya gangguan kadar albumin plasma dan kadar glukosa darah.Menganalisis hubungan kadar albumin plasma dan kadar gula darah dengan sepsis neonatorum.Penelitian analitik observasional prospektif dilakukanpada tersangka sepsis neonatorum yang dirawat di bagian Ilmu Kesehatan Anak Sub Bagian Neonati RSUP Prof. Dr. R.D. Kandou Manado. Diagnosis sepsis berdasarkan gejala klinik dan pemeriksaan laboratorium. Subyek penelitian dikelompokkan menjadi kelompok sepsis neonatorum dan kelompok non sepsis neonatorum (kelompok kontrol). Dilakukan pemeriksaan kadar albumin plasma dan glukosa darah, kemudian dianalasis secara statistik. Analisis statistik yang digunakan adalah uji korelasi Pearson Chi-Square dan uji Fisher Exact. Data diolah dengan menggunakan program SPSS 21.Hasil penelitian menunjukkan bahwa hipoalbuminemia ditemukan pada 12 (75\%) dari 16 penderita sepsis neonatorum, sedangkan pada penderita non sepsis hanya ditemukan $5(22,7 \%)$ dari 22 penderita non sepsis. Secara statistik terdapat perbedaan yang sangat bermakna $(\mathrm{p}=0,001)$. sedangkan gangguan glukosa darah (baik hipoglikemia maupun hiperglikemia) tidak terdapat perbedaan yang bermaknsa antara kedua kelompok $(\mathrm{p}=0,466)$. Simpulan: Terdapat hubungan yang sangat bermakna antara hipoalbuminemia dengan sepsis neonatorum. Tidak terdapat hubungan yang bermakna antara kadar gula darah abnormal dengan sepsis neonatorum.
\end{abstract}

Kata Kunci:sepsis neonatorum, kadar albumin plasma, kadar glukosa darah. 
Sepsis neonatorum adalah infeksi bakteri pada aliran darah bayi selama bulan pertama kehidupan. Menurut The International Sepsis Definition Conference (ISDC, 2001), sepsis adalah sindrom klinis dengan adanya Systemic Inflammatory Response Syndrome (SIRS) dan infeksi. ${ }^{1,2}$ Menurut perkiraan World Health Organi-zation (WHO) setiap hari kira-kira 8000 bayi yang baru lahir meninggal, dengan angka mortalitas neonatus (kematian dalam 28 hari pertama kehidupan) adalah 23 per 1000 kelahiran hidup, dan 99\% kematian tersebut berasal dari negara berkembang. ${ }^{3}$ Angka kejadian/insidens sepsis di negara berkembang cukup tinggi yaitu 1,8-18 per 1000 kelahiran hidup dengan angka kematian sebesar 12-68\%, sedangkan di negara maju angka kejadian sepsis berkisar antara 3 per 1000 kelahiran hidup dengan angka kematian $10,3 \%{ }^{4}$ Di Indonesia, menurut data dan informasi kementerian kesehatan RI tahun 2011 didapatkan angka kematian bayi (Infant Mortality Rate) sebesar 34/1000 kelahiran hidup. ${ }^{5}$ Data yang diperoleh dari Rumah Sakit Cipto Mangunkusumo Jakarta periode JanuariSeptember 2005, angka kejadian sepsis neonatorum sebesar $13.68 \%$ dengan angka kematian sebesara $14.18 \%{ }^{6}$

Pada sepsis terjadi pelepasan sitokin proinflamasi oleh makrofag dengan mediator-mediatornya mengaktifkan banyak jenis sel, menginisiasi kaskade sepsis, dan menghasilkan kerusakan endotel. Juga terjadi pelepasan sitokin anti inflamasi. Sitokin proinflamasi terutama berperan menghasilkan sistem imun untuk melawan kuman penyebab. Namun demikian, pembentukan sitokin proinflamasi yang berlebihan dapat membahayakan dan dapat menyebabkan syok, kegagalan multiorgan serta kematian. Sebaliknya, sitokin anti inflamasi berperan penting untuk mengatasi proses inflamasi yang berlebihan dan mempertahankan keseimbangan agar fungsi organ vital dapat berjalan dengan baik. Kerusakan utama akibat aktivasi makrofag terjadi pada endotel dan selanjutnya akan menimbulkan migrasi leukosit serta pembentukan mikrotrombin sehingga menye- babkan kerusakan organ. Inflamasi sel-sel endotelial menyebabkan vasodilatasi pada otot polos pembuluh darah dan dapat terjadi peningkatan permeabilitas pembuluh darah dan menyebabkan kebocoran kapiler. $^{7}$ Kebocoran kapiler ini menyebabkan terjadinya difusi albumin dari intravaskuler ke ekstravaskuler. Hal ini dapat memicu terjadinya hipoalbuminemia. ${ }^{8}$

Selain itu pelepasan berlebihan dari sitokin proinflamasi dan antiinflamasi yang terjadi pada sepsis tersebut dapat pula menyebabkan terjadinya perubahan patologis dalam organ vital dan sistem organ termasuk perubahan metabolisme. Produksi berlebihan dari sitokin proinflamasi dan antiinflamasi pada sepsis dapat memicu terjadinya resistensi insulin, yang menyebabkan terjadinya hiperglikemia pada awal terjadinya sepsis. Hiperglikemia pada sepsis juga berasal dari glikolisis otot dan lipolisis, kemudian glukoneogenesis dan glikolisis hati. ${ }^{9,10}$ Peningkatan produksi hormon stres seperti adrenalin, kortisol dan glukagon pada pasien sepsis neonatorum juga berperan dalam terjadinya peningkatan kadar glukosa darah. ${ }^{11}$

Pada fase selanjutnya, terjadi peningkatan kerja metabolisme tubuh yang terjadi terus-menerus, hipotermia, serta kesulitan makan pada sepsis, dapat memicu terjadinya hipoglikemia pada neonatus. Hipoglikemia merupakan sindroma metabolik yang biasa ditemukan pada pasien sepsis neonatorum, dan penelitian sebelumnya menunjukkan bahwa sekitar 58\% pasien sepsis neonatorum mengalami hipoglikemia. ${ }^{12}$ Meskipun mekanisme terjadinya hipoglikemia pada sepsis neonatorum fase selanjutnya belum dapat dijelaskan secara pasti, namun ada beberapa faktor yang berperan dalam terjadinya hipoglikemia pada pasien sepsis neonatorum, yaitu adanya peningkatan penggunaan glukosa perifer, cadangan glikogen yang rendah, dan kekurangan asupan kalori / energi yang disebabkan oleh kesulitan makan. ${ }^{13,14}$

Tujuan peneltian ini untuk menganalisis hubungan kadar albumin plasma dan glukosa darah dengan sepsis neonatorum. 


\section{METODE}

Dilakukan penelitian analitik observasional prospektif yang bertujuan menganalisis hubungan antara kadar albumin plasma dan kadar glukosa darah dengan sepsis neonatorum. Subyek penelitian adalah 38 tersangka sepsis neonatorum yang dirawab di Bagian Ilmu Kesehatan Anak Sub Bagian Neonati RSUP Prof. Dr. R. D. Kandou Manado pada bulan November 2012 sampai dengan Januari 2013. Tersangka sepsis neonatorum yaitu terdapat tiga gejala klinik dari enam kelompok gejala klinik sepsis neonato-rum, atau terdapat satu faktor resiko mayor ditambah dua faktor resiko minor.

Pemeriksaan laboratorium yang dilakukan yaitu: darah lengkap, CRP, kadar albumin plasma dan gula darah sewaktu di laboratorium Prokita Manado dan laboratorium RSUP Prof. Dr. R. D. Kandou Manado.

Penderita dengan pemeriksaan laboratorium abnormal yaitu darah lengkap dan C-Reactive Protein dimasukkan dalam kelompok sepsis neonatorum, sedangkan penderita yang tidak terbukti dengan pemeriksaan laboratorium dimasukkan dalam kelompok non sepsis neonatorum (kelompok kontrol). Selanjutnya dilakukan pemeriksaan kultur darah terhadap penderita sepsis neonatorum.

Analisis data dilakukan analisis deskriptif (rata-rata, SD, dan interval kepercayaan) dan analisis korelatif dengan uji Pearson Chi-Square dan uji Fisher Exact. Hubungan dianggap bermakna jika nilai $\mathrm{p}<0.05$. Data yang dikumpulkan diolah dengan menggunakan program SPSS versi 21.

\section{HASIL}

Jumlah subyek yang diteliti 38 tersangka sepsis neonatorum, terdiri dari 16 sepsis neonatorum dan 22 non sepsis neonatorum.

Berdasarkan distribusi subyek menurut jenis kelamin, didapatkan bahwa pada kelompok sepsis neonatorum yang berjumlah 16 penderita, terdapat sembilan (56,3\%) laki-laki dan tujuh $(43,8 \%)$ perempuan. Sedangkan pada kelompok non sepsis neonatorum yang berjumlah 22 penderita, terdapat $14(63,6 \%)$ laki-laki dan 8 (36,4\%) perempuan.

Hasil penelitian pada 16 neonatus sepsis, terdapat empat orang (25\%) dengan berat badan lahir $<2500 \mathrm{~g}$, sembilan orang (56,25\%) dengan berat badan lahir 2500 $4000 \mathrm{~g}$, dan tiga orang (18,75\%) dengan berat badan lahir $>4000$ g. Hasil penelitian pada 22 neonatus non sepsis, terdapat tujuh orang $(31,82 \%)$ dengan berat badan lahir $<2500$ g, 14 orang $(63,64 \%)$ dengan berat badan lahir 2500 - 4000 g, dan satu orang (4,55\%) dengan berat badan lahir $>4000 \mathrm{~g}$. Karakteristik subyek tertera pada Tabel 1.

Tabel 1. Karakteristik subyek penelitian.

\begin{tabular}{lcc}
\hline \multirow{2}{*}{$\begin{array}{c}\text { Berat badan } \\
\text { Lahir }\end{array}$} & $\begin{array}{c}\text { Kepsis } \\
\text { Neona- } \\
\text { torum }\end{array}$ & $\begin{array}{c}\text { Nonsis } \\
\text { Sepona- } \\
\text { Neonam } \\
\text { torum }\end{array}$ \\
\hline$-\quad<2500 \mathrm{gr}$ & $4(25)$ & $7(31,82)$ \\
$-\quad 2500-4000 \mathrm{gr}$ & $9(56,25)$ & $14(63,64)$ \\
$-\quad>4000 \mathrm{gr}$ & $3(18,75)$ & $1(4,55)$ \\
\hline Total & 16 & 22 \\
\hline
\end{tabular}

Pemeriksaan kultur darah pada 16 subyek sepsis neonatorum, terdapat lima penderita $(31,25 \%)$ sepsis neonatorum yang terbukti pada pemeriksaan kultur darah, dengan jenis kuman paling banyak ditemukan adalah Acinetobacter amitratus yaitu sebanyak tiga penderita (Tabel 2).

Hasil pemeriksaan kadar albumin pada 16 penderita sepsis didapatkan kadar albumin normal sebanyak empat $(25,0 \%)$ dan kadar hipoalbuminemia sebanyak 12 (75,0\%). Sedangkan pada 22 penderita non sepsis didapatkan kadar albumin normal sebanyak 17 (77,3\%) dan kadar hipoalbuminemia sebanyak lima (22,7\%) $(\mathrm{p}=0,001)$. Hasil selengkapnya disajikan pada tabel 3 . 
Tabel 2. Jenis kuman yang ditemukan pada penderita sepsis neonatorum.

\begin{tabular}{lc}
\hline \multicolumn{1}{c}{ Jenis Kuman } & $\begin{array}{c}\text { Jumlah } \\
\text { Penderita }\end{array}$ \\
\hline Acinetobacter amitratus & $\mathbf{3}$ \\
Alcaligenes faecialis & $\mathbf{2}$ \\
Staphylococcus aureus & $\mathbf{1}$ \\
\hline Total & 5 \\
\hline
\end{tabular}

Hasil uji Pearson Chi-Square pada tabel di atas diperoleh $\mathrm{X}^{2}=10,238$ dengan $p=0,001$. Hasil ini menunjukkan terdapat hubungan yang sangat bermakna antara kadar albumin dengan sepsis neonatorum. OR $=10,2$ dengan 95\% IK: 2,3 - 46,1.

Berdasarkan hasil pemeriksaan kadar GDS pada 16 penderita sepsis didapatkan kadar hipoglikemia sebanyak satu $(6,2 \%)$, kadar euglikemia sebanyak 11 (68,3\%), dan kadar hiperglikemia sebanyak empat (25,0\%). Sedangkan pada 22 penderita non sepsis didapatkan kadar hipoglikemia sebanyak dua (9,1\%), euglikemia sebanyak 24 (63,2\%) dan kadar hiperglikemia sebanyak 11 (28,9\%) $(p=0,466)$. Hasil selengkapnya disajikan pada tabel 4 .

Hasil uji Fisher Exact pada tabel di atas diperoleh $\mathrm{p}=0,466$. Hasil ini menunjukkan tidak terdapat hubungan yang bermakna antara kadar gula darah dengan sepsis neonatorum $(\mathrm{p}=0,466)$. $\mathrm{OR}=0,7$ dengan 95\% IK: $0,2-3,0$.

\section{BAHASAN}

Berdasarkan distribusi penderita menurut jenis kelamin, ditemukan bahwa jumlah penderita sepsis neonatorum lebih banyak ditemukan pada laki-laki yaitu sembilan dari 16 (56,3\%) dibandingkan pada perempuan yaitu tujuh dari 16 (43,8\%). Hal ini sesuai dengan penelitian yang dilakukan di Semarang pada 41 neonatus sepsis didapatkan 24 penderita sepsis neonatorum $(58,5 \%)$ berjenis kelamin lakilaki, dan 17 penderita sepsis neonatorum $(41,5 \%)$ berjenis kelamin perempuan. ${ }^{15}$

Berat badan lahir dari semua penderita sepsis neonatorum terbanyak 2500-4000 gram yaitu sembilan dari 16 (56,3\%), empat penderita dengan berat badan lahir kurang dari 2500 gram dan tiga orang lebih dari 4000 gram. Hasil ini hampir sama dengan penelitian yang dilakukan di Semarang, yaitu pada 41 neonatus sepsis didapatkan dua bayi (4,9\%) dengan berat badan lahir kurang dari 2500 g dan 39 bayi $(95,1 \%)$ dengan berat badan lahir 25004000 g. $^{15}$

Berdasarkan hasil pemeriksaan kadar albumin pada 16 penderita sepsis neonatorum didapatkan kadar albumin normal sebanyak 4 (25,0\%) dan kadar hipoalbuminemia sebanyak 12 (75,0\%). Sedangkan pada 22 penderita non sepsis didapatkan kadar albumin normal sebanyak 17 (77,3\%) dan kadar hipoalbuminemia sebanyak lima (22,7\%).

Tabel 3. Gambaran Albumin pada kelompok sepsis dan non sepsis.

\begin{tabular}{|c|c|c|c|}
\hline \multirow{2}{*}{ Gambaran Albumin } & \multicolumn{2}{|c|}{ Kelompok } & \multirow[t]{2}{*}{ Total } \\
\hline & Sepsis & Non Sepsis & \\
\hline Normal & $4(25,0)$ & $17(77,3)$ & $21(55,3)$ \\
\hline Hipoalbuminemia & $12(75,0)$ & $5(22,7)$ & $17(44,7)$ \\
\hline Total & 16 & 22 & 38 \\
\hline
\end{tabular}

Tabel 4. Gambaran GDS pada kelompok sepsis dan tidak terbukti sepsis.

\begin{tabular}{|c|c|c|c|}
\hline \multirow[t]{2}{*}{ Gambaran GDS } & \multicolumn{2}{|c|}{ Kelompok } & \multirow[t]{2}{*}{ Total } \\
\hline & Sepsis & Non Sepsis & \\
\hline Hipoglikemia & $1(6,2)$ & $2(9,1)$ & $3(7,9)$ \\
\hline Euglikemia & $12(68,3)$ & $13(59,1)$ & $24(63,2)$ \\
\hline Hiperglikemia & $4(25,0)$ & $7(31,8)$ & $11(28,9)$ \\
\hline Total & 16 & 22 & 38 \\
\hline
\end{tabular}


Hasil analisis data dengan uji korelasi Pearson menunjukkan terdapat hubungan yang sangat bermakna antara kadar albumin dan sepsis neonatorum ( $\mathrm{p}=0,001$, OR $=10,2)$. Pada penelitian ini juga didapatkan nilai odd rasio sebesar 10,2 yang berarti bahwa penderita sepsis neonatorum memiliki risiko untuk mengalami hipoalbuminemia sebesar 10 kali dibandingkan dengan penderita non sepsis neonatorum.

Pada sepsis terjadi peningkatan distribusi albumin antara intravaskular dan ekstravaskular, yang menyebabkan terjadinya perubahan kecepatan pembentukan dan penghancuran protein. Sehingga konsentrasi serum albumin akan menurun secara perlahan dan tidak akan meningkat hingga fase penyembuhan penyakit. ${ }^{16}$

Pada sepsis neonatorum terjadi pelepasan sitokin proinflamasi oleh makrofag, yang mengaktifkan banyak jenis sel, menginisiasi kaskade sepsis, dan menghasilkan kerusakan endotel. Juga terjadi pelepasan sitokin anti inflamasi. Pembentukan sitokin proinflamasi yang berlebihan pada sepsis neonatorum menyebabkan terjadinya kerusakan endotel. Inflamasi selsel endotelial menyebabkan vasodilatasi otot polos pembuluh darah dan terjadi peningkatan permeabilitas pembuluh darah dan kebocoran kapiler. ${ }^{7}$ Kebocoran kapiler ini menyebabkan terjadinya difusi albumin dari intravaskuler ke ekstravaskuler, yang menyebabkan terjadinya hipoalbuminemia pada penderita sepsis neonatorum. ${ }^{8}$

Pada sepsis neonatorum juga terjadi perubahan dalam sintesis albumin. Bila terjadi respons akut terhadap inflamasi dan sepsis, maka terjadi peningkatan Protein Creaktif (C-reactive protein), dan terjadi pelepasan TNF- $\alpha$ dan IL-6 yang berperan dalam penurunan transkripsi gen albumin dan mengakibatkan penurunan sintesis albumin. Respons inflamasi yang terus menerus menyebabkan gangguan sintesis albumin yang berkepanjangan. Juga terjadi perubahan dalam katabolisme albumin pada sepsis dan sangat mungkin bahwa endotel vaskular yang berperan dalam degradasi albumin ini. ${ }^{16,17}$

Penelitian yang dilakukan oleh Qian
SY dan Liu J di China melaporkan bahwa dari 143 kelompok penderita sepsis pada anak, didapatkan 83 penderita $(59,4 \%)$ mengalami hipoalbuminemia. Penelitian tersebut juga melaporkan bahwa terdapat hubungan yang bermakna antara tingkat / derajat penyakit dengan kadar albumin. ${ }^{18}$

Berdasarkan hasil pemeriksaan kadar GDS pada 16 penderita sepsis didapatkan kadar hipoglikemia sebanyak satu $(6,2 \%)$, kadar euglikemia sebanyak 11 (68,3\%), dan kadar hiperglikemia sebanyak empat (25,0\%). Sedangkan pada 22 penderita non sepsis didapatkan kadar hipoglikemia sebanyak dua $(9,1 \%)$, euglikemia sebanyak 24 (63,2\%) dan kadar hiperglikemia sebanyak 11 (28,9\%).

Hasil analisis data dengan uji Fisher Exact menunjukkan tidak terdapat hubungan yang bermakna antara kadar gula darah dengan sepsis neonatorum $(p=0,466)$.

Pada sepsis terjadi stress dimana terjadi aktivasi sistem aksis hypothalamuspituitary-adrenal (HPA) dengan dilepaskannya kortisol dari kelenjar adrenal. Peningkatan kortisol mengakibatkan peningkatan pelepasan epinefrin, norepinefrin, glukagon dan growth hormone. Selain itu pada sepsis juga terjadi pelepasan berbagai sitokin seperti IL-1, IL-6, dan TNF- $\alpha$ yang berperan dalam terjadinya resistensi insulin pada sepsis. Adanya kombinasi berbagai faktor tersebut memegang peranan penting terjadinya hiperglikemia pada sepsis. ${ }^{19-21}$

Hiperglikemia biasa terjadi pada awal terjadinya sepsis, dan hal ini dapat dianggap menguntungkan karena menyediakan suplai glukosa untuk energi yang adekuat untuk organ-organ tubuh. Namun jika keadaan kritis sepsis ini berlanjut terus maka terjadi perubahan-perubahan patologis yang memicu terjadinya hipoglikemia pada fase selanjutnya. ${ }^{13,14}$

Pada hasil penelitian ini ditemukan tidak ada hubungan yang bermakna antara kadar gula darah abnormal dalam hal ini hipoglikemia dan hiperglikemia dengan sepsis neonatorum. Hal ini dapat disebabkan oleh karena penderita sepsis neonatorum yang menjadi sampel penelitian telah 
melewati tahap hiperglikemia pada fase awal terjadinya sepsis neonatorum, dan belum sampai pada tahap hipoglikemia. Karena dalam penelitian ini pemeriksaan kadar gula darah dilakukan hanya satu kali pada setiap penderita sepsis neonatorum, tanpa melakukan monitoring terus-menerus pada penderita sepsis neonatorum. Hal ini juga dapat disebabkan oleh karena pemeriksaan kadar glukosa darah pada beberapa penderita sepsis neonatorum dilakukan pada saat penderita telah mendapatkan pengobatan atau terapi dari rumah sakit, sehingga kondisi pasien telah berada dalam fase penyembuhan.

Penelitian yang dilakukan oleh Campos dkk di Brazil melaporkan bahwa 99\% dari 55 penderita sepsis neonatorum mengalami perubahan pada kadar glukosa darah, dengan hipoglikemia menjadi kelainan yang paling banyak ditemukan yaitu sebesar $58 \%{ }^{12}$

Penelitian lain yang dilakukan oleh Sultan Ahmad dan Riffat Khalid di Pakistan melaporkan bahwa sebagian besar penderita sepsis neonatorum dan probable sepsis memiliki kadar glukosa antara 40 dan $100 \mathrm{mg} / \mathrm{dl}$. Akan tetapi penderita sepsis neonatorum dan probable sepsis yang memiliki kadar glukosa dibawah $40 \mathrm{mg} / \mathrm{dl}$ dan diatas 200 mg/dl memiliki mortatilitas yang lebih tinggi. ${ }^{11}$

\section{SIMPULAN}

Berdasarkan hasil penelitian ini maka dapat disimpulkan bahwa:

1. Terdapat hubungan yang bermakna antara hipoalbuminemia dengan sepsis neonatorum. Penderita sepsis neonatorum memiliki kadar albumin yang lebih rendah dibandingkan dengan penderita non sepsis neonatorum.

2. Tidak terdapat hubungan yang bermakna antara kadar gula darah abnormal dengan sepsis neonatorum. Kadar glukosa darah pada penderita sepsis neonatorum sama dengan kadar glukosa darah pada penderita non sepsis neonatorum, yaitu normal.

\section{UCAPAN TERIMA KASIH}

Terima kasih kepada semua pihak yang baik secara langsung maupun tidak langsung telah menumbuhkan gagasan kepada penulis untuk menyelesaikan tulisan ini.

\section{DAFTAR PUSTAKA}

1. Haque KN. Definitions of bloodstream infection in the newborn. Pediatr Crit Care Med. 2005; 6(3):S45-9.

2. Goldstein B, Giroir B, Randolph A. International pediatric sepsis consensus conference: definitions for sepsis and organ dysfunction in pediatrics. Pediatr Crit Care Med. 2005; 6(1):2-8

3. WHO. Newborn health epidemiology. Diakses dari: www.who.int/maternal_child_adolescent/e pidemiology/newborn/en/ (tanggal akses : 2 Oktober 2012)

4. Watson RS et al. The epidemiology of severe sepsis in children in the United States. Am J Respir Care Med. 2003; 167:695-701.

5. Data dan informasi. Pusat Data dan Informasi. Kementerian Kesehatan RI. 2011: 2 .

6. Juniatiningsih A, Aminullah A, Firmansyah A. Profil Mikroorganisme Sepsis Neonatorum di Departemen Ilmu Kesehatan Anak Rumah Sakit Cipto Mangunkusumo Jakarta. Sari Pediatri. 2008; 10(1):60-5.

7. Short MA. Linking the sepsis triad of inflammation, coagulation and suppressed fibrinolysis to infants. Adv Neonat Care 2004; 5:258-73.

8. Ballmer PE. Causes and mechanisms of hypoalbuminaemia. Clinical Nutrition. 2001; 20(3): 271-3.

9. Das UN. Insulin in sepsis and septic shock. JAPI. 2003; 51:695-700.

10. Hirasawa $H$, Oda $S$, Nakamura $M$. Blood glucose control in patients with severe sepsis and septic shock. World Journal of Gastroenterology. 2009; 15(33):4132-136.

11. Ahmad S, Khalid R. Blood glucose levels in neonatal sepsis and probable sepsis and its association with mortality. Journal of the College of Physicians and Surgeons Pakistan. 2012; 22(1):15-18. 
12. Campos DP, Silva MV, Machado JR, Castellano LR, Rodrigues V, Barata CHC. Early-onset neonatal sepsis: cord blood cytokine levels at diagnosis and during treatment. Jornal de Pediatria. 2010; 86(6):509-14.

13. Fernandez BA, Perez IC. Neonatal hypoglycemia - current concepts. Hypoglycemia - Causes and Occurences. 2011. Madrid, Spain.

14. Perkin RM, Swift JD, Newton DA, Anas NG. Pediatric Hospital Medicine: Textbook of Inpatient Management 2nd edition; 2008; Philadelphia, USA.

15. Rahardjani KB. Hubungan Antara Malondialdehyde (MDA) dengan Hasil Luaran Sepsis Neonatorum. Sari Pediatri. 2010; 12(2):82-7.

16. Nicholson JP, Wolmarans MR, Park GR. The role of albumin in critical illness. Br J Anaesth 2000; 85:599-601.

17. Peralta $\mathbf{R}$ et al. Hypoalbuminemia clinical presentation. Di akses dari www.emedicine.medscape.com. (tanggal akses : 2 Oktober 2012)

18. Qian SY, Liu J. Relationship between serum albumin level and prognosis in children with sepsis, severe sepsis or septic shock. Zhonghua Er Ke Za Zhi. 2012; 50(3):184-87.

19. Muniandy S, Qvist R, Yan GOS, Bee CJ, Chu YK, Rayappan AV. The oxidative stress of hyperglycemia and the inflammatory process in edothelial cells. The Journal of Medical Investigation. 2009; 56:6-10.

20. Wen-Kei $Y$, Wei-Qin $L$, Ning $L$, JieShou L. Influence of acute hyperglycemia in human sepsis on inflammatory cytokine and counterregulatory hormone concentrations. World J Gastroenterol. 2003; 9(8):1824-27.

21. Andersen SK, Gjedsted J, Christiansen C, Tannesen E. The roles of insulin and hyperglycemia in sepsis pathogenesis. Journal of Leukocyte Biology. 2004; 75(3): 413-21. 